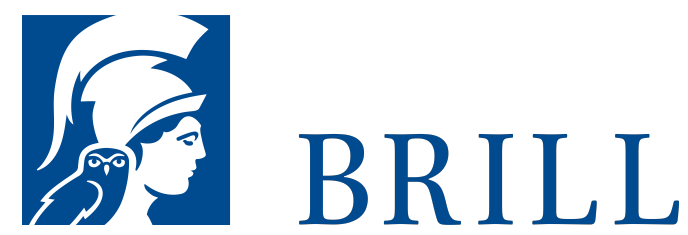

\title{
Endliches Subjekt
}

Gleichheit und der Ort der Differenz bei Hobbes und Rousseau

Author: Ariane Bürgin

Ausgehend von der feministischen Debatte um Gleichheit und Differenz befragt die Autorin die Idee der Gleichheit bei Hobbes und Rousseau - zwei Theoretikern, die auf die Gleichheitsprämisse in ihrer modernen, politisch-normativen Ausgestaltung maßgeblich Einfluss ausübten. Unter Berücksichtigung von Jacques Lacans Theorie des gespaltenen, vom Mangel gezeichneten Subjekts wird dargelegt, dass die Thematisierung der Gleichheit bei Hobbes und Rousseau auf spezifischen Bestimmungen des Subjekts fußt, in deren Zentrum das - allerdings gänzlich verschieden gefasste Verhältnis zum Anderen steht.

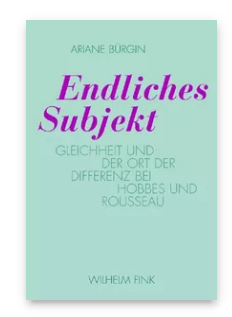

Pages: 188

Seiten

Language:

German

Subjects:

General,

Philosophy

Publisher: Brill |

Fink

E-Book (PDF)

Released online:

13 Jan 2020

ISBN: 978-3-

8467-4581-6

List price

USD \$ $\$ 48.00$

Paperback

Publication date:

21 May 2008

ISBN: 978-3-

7705-4581-0

List price

USD \$48.00 
For more information see brill.com

Order information: Order online at brill.com +44330 333 0049 | customerservices@brill.com Submission information: brill.com/authors

Titles published by Brill | Fink, Brill | mentis or Brill | Schöningh: +49(o)715413279216| brill@brocom.de 